\title{
Recent advances in renal transplantation: antibody-mediated rejection takes center stage

\author{
Eric Pouliquen ${ }^{1-3 \#}$, Alice Koenig ${ }^{1-3 \#}$, Chien Chia Chen ${ }^{1-3}$, Antoine Sicard ${ }^{1-3}$, \\ Maud Rabeyrin ${ }^{4}$, Emmanuel Morelon ${ }^{1-3}$, Valérie Dubois ${ }^{5}$ \\ and Olivier Thaunat*1-3
}

Addresses: ${ }^{1}$ Hospices Civils de Lyon, Hôpital Edouard Herriot, Service de Transplantation, Néphrologie et Immunologie Clinique, Lyon, France; ${ }^{2}$ Institut National de la Santé et de la Recherche Médicale U1111, Lyon, France; ${ }^{3}$ Unité de Formation et de Recherche Lyon Est, Université de Lyon, Lyon, France; ${ }^{4}$ Laboratoire d'anatomopathologie, Hospices Civils de Lyon, Hôpital Edouard Herriot, Lyon, France;

${ }^{5}$ Laboratoire d'Histocompatibilité, Etablissement Français du Sang, Lyon, France

\# These authors contributed equally to this work.

* Corresponding author: Olivier Thaunat (olivier.thaunat@chu-lyon.fr)

Fl000Prime Reports 2015, 7:5I (doi:10.12703/P7-5I)

All FI000Prime Reports articles are distributed under the terms of the Creative Commons Attribution-Non Commercial License (http://creativecommons.org/licenses/by-nc/3.0/legalcode), which permits non-commercial use, distribution, and reproduction in any medium, provided the original work is properly cited.

The electronic version of this article is the complete one and can be found at: http://fl000.com/prime/reports/m/7/5।

\begin{abstract}
Overlooked for decades, antibodies have taken center stage in renal transplantation and are now widely recognized as the first cause of allograft failure. Diagnosis of antibody-mediated rejection has considerably improved with identification of antibody-mediated lesions in graft biopsies and advances made in the detection of circulating donor-specific antibodies. Unfortunately, this progress has not yet translated into better outcomes for patients. Indeed, in the absence of a drug able to suppress antibody generation by plasma cells, available therapies can only slow down graft destruction. This review provides an overview of the current knowledge of antibody-mediated rejection and discusses future interesting research directions.
\end{abstract}

\section{The original sin of transplant immunologists}

Since the first successful attempt performed in 1954, kidney transplantation has emerged as the best option for end-stage renal failure, providing both a better quality of life and better survival to patients, for a third of the cost of hemodialysis [1]. However, because in clinical transplantation the donor is from the same species but genetically different, the adaptive immune system of the recipient recognizes alloantigens expressed by the graft: that is, proteins present in different allelic forms encoded at the same gene locus in different individuals, such as major histocompatibility complex (MHC) molecules. An immune response that develops against alloantigens leads to the destruction of the transplanted organ, a process termed "rejection", which remains the first cause of renal allograft failure.
The adaptive immune system comprises two distinct effector mechanisms-cytotoxic T cells and antibodiesand the question of which of these mechanisms contribute to graft rejection has been central from the very beginning of transplant immunology. Gorer [2] was the first to report the development of antibodies against alloantigens. In this early era, however, most of the knowledge pertaining to the immunological mechanisms involved in rejection was derived from the skin graft model popularized by Billingham and Medawar [3]. The observations made in this model that (i) skin allografts were not rejected in animals lacking $\mathrm{T}$ cells and that (ii) adoptive transfer of purified $\mathrm{T}$ cells, but not alloantibodies, was sufficient to restore the rejection of skin allografts in immunodeficient rodents [4] stemmed from the concept that $\mathrm{T}$ cells were "the" cell subset 
responsible for rejection of allogeneic transplants, a vision that prevailed until the 2000s.

During the last decade, however, experimental and clinical studies have challenged this "T cell-centric" vision and brought antibodies back to the center stage of transplant immunology [5].

\section{Transplantation versus grafting: vessels' origin matters}

The first evidence that humoral immunity can be deleterious in the setting of clinical transplantation came in the early 1970s from seminal clinical observations that (i) the presence of preformed circulating donor-specific antibodies (DSAs) was associated with a high risk for "hyperacute rejection" (that is, immediate graft failure due to widespread capillary thrombosis and necrosis [6]) and that (ii) de novo generation of DSAs after transplantation correlated with poor outcomes and histologic evidence of vascular obliterative lesions, named "allograft vasculopathy" [7].

These clinical findings were in apparent contradiction with the resistance of skin grafts to passive transfer of alloantibodies [4]. The origin of this discrepancy lies in the fact that, in contrast with grafted tissue, whose vascularization develops from the recipient, the vessels of renal allografts are anastomosed to those of the recipient, placing donor allogeneic endothelial cells in direct contact with the recipient's circulation. This makes a crucial difference in the sensitivity of renal transplants to the humoral arm of the recipient's alloimmune response. Antibodies are indeed massive proteins (150 kDa) largely sequestrated in blood circulation [8]. Accordingly, when Russell and colleagues [9] performed passive transfer of alloantibodies to immunodeficient mice transplanted with allogenic hearts in the late 1990s, they observed that continuing injections of antiserum were sufficient to drive the development of obstructive coronary lesions. This first experimental demonstration that humoral immunity is the prime instigator of allograft vasculopathy [9] has since been confirmed in other models [10] and in the clinical setting [11].

\section{Pathophysiology of antibody-mediated rejection Humoral response to allogeneic transplant}

Recent experimental studies have shed light on the natural history of antibody-mediated rejection (AMR) (Figure 1) [12,13]. The sequence starts with the generation of antibodies directed against the graft (DSAs). Although highly polymorphic mismatched HLA molecules represent the most documented targets for DSAs, it is clear that DSAs can also be directed against other kinds of molecular targets, including polymorphic minor histocompatibility antigens [14] and, following a breakdown of B-cell tolerance [15], non-polymorphic autoantigens [16]. Although some studies suggest that "non-HLA" antibodies could participate in the development of rejection [17], particularly those expressed on the endothelial cell surface [18], such as anti-angiotensin II type-1 receptor antibodies $[19,20]$, their exact pathological potential remains a matter of debate, and hereafter, we will focus on anti-donor HLA antibodies (abbreviated DSAs).

The generation of such high-affinity, class-switched alloantibodies directed against a protein antigen requires the development of a germinal center reaction, which implies the expansion of $\mathrm{CD}^{+}{ }^{+} \mathrm{T}$ cells with indirect allospecificity (that is, $\mathrm{CD} 4^{+} \mathrm{T}$ cells whose $\mathrm{T}$ cell receptors recognize alloantigens processed and presented in the context of MHC class II molecules expressed by recipient antigen-presenting cells) (Figure 1) [21].

The initiation of a $\mathrm{T}$ cell-dependent humoral immune response takes place within the recipient's canonical secondary lymphoid organs: spleen and draining lymph nodes (Figure 1) [22]. However, recent evidence suggests that, with time, immune effectors infiltrating the graft sometimes organize into ectopic lymphoid tissue (Figure 1) $[23,24]$, which harbors the maturation of a local humoral immune response [25] that can also participate in the rejection process [26].

\section{Implication of the classical complement pathway in acute antibody-mediated rejection}

Binding of circulating DSAs to directly accessible graft endothelial cells can trigger the activation of the classical complement pathway, a central process in the pathophysiology of acute AMR (that is, AMR with acute graft dysfunction). Briefly, C1q binding to DSAs complexed with antigen activates the serine esterases $\mathrm{C} 1 \mathrm{~s}$ and $\mathrm{C} 1 \mathrm{r}$, which allow the cleavage of $\mathrm{C} 4$. This results in the deposition of $\mathrm{C} 4 \mathrm{~d}$ in tissue and the assembly of the classical pathway C3 convertase. The latter cleaves C3 into C3a and C3b. C3a is a potent proinflammatory mediator that causes leukocyte recruitment, whereas C3b propagates the complement cascade, leading to the formation of sublytic membrane attack complexes responsible for the activation of endothelial cells (Figure 1) [27].

\section{Complement is dispensable for chronic/subclinical antibody-mediated rejection}

In contrast with acute AMR, activation of the classical complement pathway appears to be dispensable for the development of chronic/subclinical AMR lesions. The first evidence supporting this concept came from Colvin and colleagues, who transplanted RAG KO immunodeficient 
Figure I. Schematic representation of antibody-mediated rejection pathophysiology

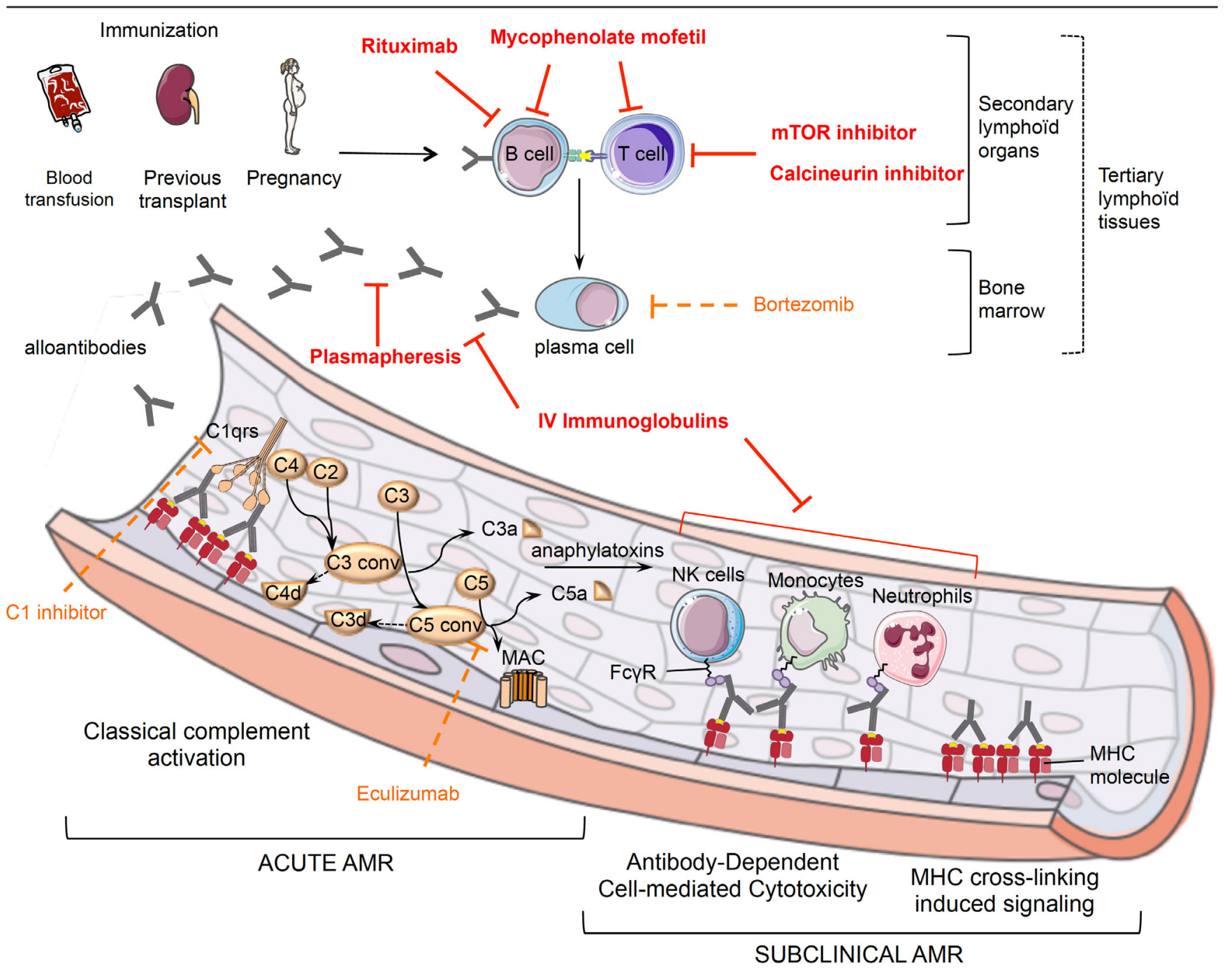

Mechanisms of action of therapies are indicated. Therapies currently used are in bold red; drugs under evaluation are in dashed orange. AMR, antibodymediated rejection; Conv, convertase; IV, intravenous; MAC, membrane attack complex; MHC, major histocompatibility complex; mTOR, mammalian target of rapamycin; NK, natural killer.

mice with allogenic hearts and observed that the passive transfer of non-complement-fixing DSAs was sufficient to promote allograft vasculopathy [28]. Innate immune cells can indeed bind to the fragment crystallizable $(\mathrm{Fc})$ region of antibodies and release lytic enzymes (a mechanism called antibody-dependent cell-mediated cytotoxicity, or ADCC) (Figure 1), which mediate smoldering endothelial cell damage. The recognition of this pathological mechanism in the clinic led to the recognition of C4d-negative forms of AMR, often diagnosed on screening biopsy (that is, subclinical AMR) [29]. Chronic vascular inflammation in turn promotes the progressive development of typical vascular lesions (that is, transplant glomerulopathy, allograft vasculopathy, and lamination of the peritubular capillary basement membrane). Finally, progressive tissue destruction leads to irreversible loss of graft function, proteinuria, and hypertension (that is, chronic AMR).

The question of which type of innate immune effectors plays the key role in AMR is still a matter of debate. Hirohashi and colleagues [30] showed that depletion of natural killer cells was sufficient to abrogate DSAinduced arterial lesions. The validity of these experimental data in the clinic is supported by transcriptomic analysis of renal graft biopsies from patients with chronic AMR [31]. However, it is likely that other cell types, including neutrophils and monocytes, are also involved (Figure 1). Recent data from the clinic even suggest that 
expanded circulating cytomegalovirus-responsive $\gamma \delta$ T cells could participate in allograft lesions mediated by DSAs through ADCC, offering a new pathophysiologic link between cytomegalovirus infection and allograft dysfunction [32].

Finally, some experimental studies demonstrated that DSAs can directly trigger activating signals in endothelial cells through MHC molecule cross-linking (Figure 1), which promotes exocytosis of Weibel-Palade bodies, activates the coagulation cascade, and increases the expression of adhesion molecules and growth factors [33]. This mechanism could also participate in the development of complement-independent AMR lesions.

\section{One pathophysiology, several clinical courses}

If clinical studies have largely validated the sequence of molecular events established in experimental models of AMR [34,35], the progression along the successive stages of the pathology can, however, follow different clinical courses [36]. For some patients, AMR is made clinically patent by the occurrence of one or more episodes of graft dysfunction. In contrast, other kidney graft recipients with DSAs experience smoldering forms of AMR (that is, subclinical AMR), characterized by persistent microvascular abnormalities without acute graft dysfunction [29].

The quantity (titer) of circulating DSAs is an obvious factor influencing the clinical expression of the disease $[37,38]$. Qualitative factors, linked to antibody structure, are also important sources of clinical heterogeneity. The immunoglobulin (Ig) molecule is shaped like a Y, with two identical halves, each made up of a heavy chain and a light chain. The two arms of the $\mathrm{Y}$, each formed by the amino terminal extremity of a heavy chain and a light chain, contain the antigen-binding site. Higher avidity could explain why some patients develop clinically patent AMR with low DSA titer. At the base of the Y, composed of the carboxy terminal extremity of the constant region of the two heavy chains, is the Fc region. During a T cell-dependent humoral response, class-switch recombination occurs in the germinal center, leading to the replacement of the constant region of the Ig heavy chain. Accordingly, anti-HLA alloantibodies of a wide range of isotypes (IgG1, G2, G3, G4, Ig A1, A2, IgM) can be eluted from explanted renal allografts [39]. Through their Fc portion, each heavy-chain isotype displays a different capability to bind C1q (and therefore to trigger the classical complement pathway) and to recruit immune effectors through their Fc receptors. Interestingly, it has been reported that patients with exclusively weak complement-activating DSAs (that is, IgG1 and IgG4) tend to experience less acute AMR and better outcome [40-42]. Another possible source of heterogeneity comes from the carbohydrate chains that are attached to Fc [43]. Age, gender, and disease status are all factors influencing Ig Fc glycosylation [43]. In the case of IgG, terminal sugars affect the binding to the $\mathrm{F} \gamma \gamma \mathrm{RIII}$ receptor and thereby influence ADCC, whereas terminal galactose residues affect antibody binding to $\mathrm{C} 1 \mathrm{q}$ and thereby modulate IgG complementdependent activity [44].

\section{Challenges in antibody-mediated rejection diagnosis}

The recognition of subclinical forms of the disease implies that, upon detection of circulating DSAs, a renal biopsy should be performed, even in the absence of clinically patent graft dysfunction (that is, "screening biopsies") [45]. In 2005, the Banff Conference on Allograft Pathology defined criteria for diagnosing AMR [46], which include the three following cardinal features: (a) presence of circulating DSAs, (b) morphologic evidence of antibody-mediated tissue injury (glomerular or peritubullar capillaries inflammation score $>0$ ), and (c) positive staining for C4d in peritubular capillaries (used as a surrogate marker for local classical complement pathway activation) [47]. Since then, however, the value of $\mathrm{C} 4 \mathrm{~d}$ for the diagnosis of AMR has been questioned. Although there is little doubt that complement activation is important for DSAs to trigger clinically patent "acute" AMR [48], a high percentage of graft biopsies with morphologic evidence of antibody-mediated tissue injury are C4dnegative [49]. This notion has been strengthened by transcriptomic analyses, which demonstrate a similar increased level of expression for endothelial genes in C4d-negative and C4d-positive AMR biopsies [50]. Finally, the direct demonstration that DSAs can trigger chronic arterial lesions in murine experimental models without complement participation [28] led to the recognition of C4d-negative AMR in the most recent Banff classification [51].

\section{(R)evolution in anti-HLA antibody monitoring}

In line with the growing clinical interest in AMR, tools available for DSA detection have considerably improved over the last few decades [52]. Historically, the first test to detect circulating DSAs was the complement-dependent cytotoxicity (CDC) assay performed between recipient sera and donor lymphocytes.

In the early 1980s, flow cytometry cross-match (FCXM) emerged as an alternative to CDC assays [53]. Although the FCXM was 10- to 100-fold more sensitive to detect DSAs, it rapidly appeared that T cell or (especially) B-cell FCXM (or both) lacked specificity because of (i) autoantibodies binding to donor lymphocytes and (ii) binding of Ig to lymphocyte Fc receptors (independently of their antigen specificity). These limitations explained the 
discrepancies among centers in outcomes of patients with positive FCXM and led to confusion regarding the clinical utility of the FCXM.

The revolutionary development in DSA screening was the introduction of solid-phase membrane-independent assays. The enzyme-linked immunosorbent assay was the first assay to use purified HLA proteins [54] and was soon followed by flow cytometric and multiplex assays. All of these approaches coupled purified HLA antigens to inert plastic or latex. Currently, genetic engineering is being used to produce microparticles coated with single HLA alleles, offering the possibility not only to detect circulating DSAs with exquisite sensitivity but also to readily identify their specificities [55].

Solid-phase antibody detection assays are not devoid of limitations [56]. Technical issues include the following: (i) the different nature (natural versus recombinant) of antigens on screening and specificity products; (ii) the definition of the threshold level (mean fluorescent intensity, or MFI) to consider an antibody as being "present"; (iii) the conformation of HLA antigens (intact or denatured) upon adherence to the beads; (iv) the density of antigen on the beads; and (v) interfering factors that mask the detection of DSAs (sometimes named the "prozone phenomenon") [57].

Although the solid-phase antibody detection assays have permitted the detection of DSAs not detectable by CDC assay, the clinical significance of these antibodies is incompletely understood. Recent studies have indeed shown that not all DSAs identified by solid-phase antibody detection assays predict a poor outcome [58], underlying the need for tools allowing better stratification of the risk.

\section{Risk stratification in antibody-mediated rejection}

Some approaches to stratifying the risk of graft loss in AMR rely on graft biopsy. Bachelet and colleagues [59] have shown, for instance, that the presence of DSAs bound to the graft (as assessed by solid-phase antibody detection assays on eluate from needle core graft biopsies) was predictive of unfavorable short-term transplant outcome. Coupling analysis of histological features with transcriptomic profiling of graft biopsy with the "molecular microscope" system seems to be another interesting way to improve risk stratification in AMR [60].

As discussed above, complement activation is not necessary for DSAs to drive vascular lesions. However, because the combination of complement-dependent and -independent mechanisms is synergistically deleterious for the graft, complement activation is a good candidate for risk stratification in AMR. C4d staining in renal capillaries showed poor performance in predicting AMR outcome in several independent studies [49,50,61,62].

Recently, several manufacturers have modified their solid-phase antibody detection assays to directly assess the capacity of circulating DSAs to bind the complement components of the classical pathway (that is, C1q [63], C4d [64], or C3d [62]). A recent study has demonstrated the value of these assays in predicting allograft loss in AMR [62]. However, the direct correlation observed between DSA titer (MFI value measured with classic solid-phase antibody detection assays) and DSA ability to trigger complement activation (which was predicted by basic molecular immunology [65]) questions the clinical utility of these tests. One possibility could be to spare them for AMR patients with low DSA titer, for which a C3d-binding assay has shown promise in predicting graft loss [62].

\section{Therapeutic challenges}

It is widely accepted that a significant proportion of what were once called "cortico-resistant rejections" were, in fact, AMR. Although anti-thymocyte globulin (ATG), which contains activity against numerous cell surface proteins, can induce complement-independent apoptosis of naive, activated B cells, and plasma cells [66], ATG alone is ineffective in AMR.

Historically, the first attempt to reduce DSAs' deleterious effects on graft endothelium relied on the use of highdose intravenous immunoglobulin (IVIg), a therapy with incompletely understood mechanisms, which could accelerate DSA catabolism, act as scavenger of activated complement, and down-modulate the activation of innate immune effectors [67].

Although IVIg remains an essential component of AMR treatment, several studies have shown that better outcomes were achieved when it was combined with a rapid depletion of circulating DSAs (with plasmapheresis [68] or immunoadsorption [69]). As expected from its mechanism of action, this costly and tedious therapeutic approach is not curative (DSA-producing plasma cells are not affected) and therefore has only a suspensive effect on antibody-mediated graft destruction [70]. In short, it is realistic to consider that, in most cases, IVIg and plasmapheresis will (at best) turn an acute form of AMR into a subclinical disease.

In an attempt to provide a sustained therapeutic effect, anti-CD20 monoclonal depleting antibody (rituximab), a widely established treatment of B cell lymphoma, has 
been tested in AMR. Although the rationale of this approach can be questioned (since CD20 is not expressed on plasma cells), several small retrospective series reported promising results $[71,72]$ and a recent meta-analysis of 10 of these studies concluded that rituximab was a reasonable therapeutic option in the treatment of AMR. The first controlled trial, published in 2009 [68], indeed concluded that a plasmapheresis/IVIg/ anti-CD20 regimen was associated with better graft outcome in comparison with IVIg alone. However, the benefit reported could be due to either DSA removal or B cell depletion. In fact, the only multicenter randomized study-Impact of Treatment With Rituximab on the Progression of Humoral Acute Rejection After Renal Transplantation (RITUX-ERAH) (ClinicalTrials.gov Identifier: NCT01350882 http://clinicaltrials.gov/ct2/show/ NCT01350882)-performed to investigate the effect of rituximab on AMR, found no difference at 12 months on graft loss, epidermal growth factor receptor (eGFR), proteinuria, and glomerulitis score between placebo and rituximab groups [73]. Therefore, the benefits reported in small retrospective series should be carefully considered since methodological and positive publication bias seems likely. Furthermore, the use of rituximab in this context may be associated with a higher risk of infection $[74,75]$.

We have already seen above that intragraft complement activation was associated with worse outcomes in AMR. Thus, blocking complement cascade seems to be an attractive therapeutic option, especially for patients with DSAs able to bind complement components in solidphase assays [62]. Experimentally, C1 blockade prevented acute AMR of kidney allografts in allosensitized baboons [76]. Although C1 inhibition has not been tested in clinical AMR yet, a C1 inhibitor for treatment of patients with hereditary angioedema is already available [77]. Eculizumab is a humanized monoclonal antibody that targets complement protein C5 initially developed to treat paroxysmal nocturnal hemoglobinuria [78]. Eculizumab appears to be effective in protecting renal allografts from post-transplant recurrence of atypical hemolytic uremic syndrome [79]. Only a few case reports with short follow-ups are currently available in the literature regarding eculizumab efficiency in AMR [80]. Although eculizumab in prophylaxis appears to be effective at preventing acute AMR in sensitized patients [81], it is unclear whether eculizumab contributes to the development of accommodation and therefore how long treatment should continue (a particularly important issue given the expense of the drug). Another important limitation of complement blockades is the fact that these approaches are unlikely to prevent the development of chronic antibody-mediated lesions, which also result from complement-independent mechanisms.
In fact, only the disappearance of DSAs from the recipient's circulation could stop graft destruction in AMR (and achieve efficient desensitization). In the absence of therapy able to deplete selectively DSAproducing plasma cells, bortezomib-a selective inhibitor of the 26S proteasome widely used for the treatment of multiple myeloma-has been proposed. Bortezomib induces apoptosis among plasma cells in whole bone marrow cell cultures, thereby reducing the secretion of alloantibodies (but also vaccinal antibodies) in vitro [82]. Clinical experience with this drug in the context of AMR is still limited [83], but, based on these promising preliminary results, prospective studies have been launched to evaluate bortezomib efficiency and tolerance profile in this indication (ClinicalTrials.gov Identifier: NCT02201576 http://clinicaltrials.gov/ct2/show/NCT02201576, ClinicalTrials.gov Identifier: NCT01873157 http://clinicaltrials. gov/ct2/show/NCT01873157).

In the absence of efficient curative treatment for AMR, emphasis should be placed on "primary" prevention of de novo DSAs. This objective requires (i) avoiding futile transfusions in candidates for transplantation, (ii) maximizing HLA compatibility between donor and recipient, (iii) improving adherence to immunosuppressive treatments [5], and (iv) optimizing maintenance of immunosuppression. Particular attention should be paid to this issue when immunosuppression is reduced [70]. In this regard, strategies aiming at suppressing anticalcineurin appear to be particularly at risk of de novo DSA generation $[84,85]$.

\section{Conclusions}

In the shadows since the early era of transplantation, DSAs have recently been recognized as the first cause of allograft failure. Although important advances have been made in AMR diagnosis in this last decade, a curative therapy is still lacking. Since current therapeutic strategies can only slow down antibody-mediated destruction of the graft, special emphasis should be placed on the prevention of DSA generation. Finally, it should be kept in mind that $\mathrm{B}$ cells are much more than plasma cell precursors. B cells are endowed with important antibodyindependent functions, including immunoregulation [86] and antigen presentation to T cells [87], which are increasingly recognized as key in the balance between rejection/tolerance of solid organ transplants.

\section{Abbreviations}

ADCC, antibody-dependent cell-mediated cytotoxicity; AMR, antibody-mediated rejection; ATG, antithymocyte globulin; CDC, complement-dependent cytotoxicity; DSA, donor-specific antibody; Fc, fragment crystallizable; FCXM, flow cytometry cross-match; Ig, immunoglobulin; 
IVIg, intravenous immunoglobulin; MFI, mean fluorescent intensity; MHC, major histocompatibility complex.

\section{Disclosures}

The authors declare that they have no disclosures.

\section{Acknowledgments}

The authors are supported by the CENTAURE Transplantation Research Network, the Agence Nationale de la Recherche (ANR- 12-PDOC-0019.01), the Hospices Civils de Lyon, and the Fondation pour la Recherche Medicale. The authors wish to thank Mathilde Koenig and Servier Medical Art (creativecommons.org/licenses/ by/3.0/fr/) for their contribution to the design of the figure.

\section{References}

I. Schieppati A, Remuzzi G: Chronic renal diseases as a public health problem: epidemiology, social, and economic implications. Kidney international. Supplement 2005:S7-SI0.

2. Gorer PA: The antigenic basis of tumour transplantation. J Pathol 1938, 47:231-52.

3. Billingham RE, Medawar PB: The Technique of Free Skin Grafting in Mammals. Journal of Experimental Biology 195I, 28:385-402.

4. Benichou G, Yamada Y, Yun S, Lin C, Fray M, Tocco G: Immune recognition and rejection of allogeneic skin grafts. Immunotherapy 20II, 3:757-70.

5. Sellarés J, de Freitas DG, Mengel M, Reeve J, Einecke G, Sis B, Hidalgo LG, Famulski K, Matas A, Halloran PF: Understanding the causes of kidney transplant failure: the dominant role of antibody-mediated rejection and nonadherence. American journal of transplantation: official journal of the American Society of Transplantation and the American Society of Transplant Surgeons 2012, 1 2:388-99.

\section{FlOOOPrime}

\section{RECOMMENDED}

6. Patel R, Terasaki PI: Significance of the positive crossmatch test in kidney transplantation. The New England journal of medicine 1969, 280:735-9.

7. Jeannet M, Pinn VW, Flax MH, Winn HJ, Russell PS: Humoral antibodies in renal allotransplantation in man. The New England journal of medicine 1970, 282: I I I-7.

8. Hall JG, Smith ME, Edwards PA, Shooter KV: The low concentration of macroglobulin antibodies in peripheral lymph. Immunology 1969, 16:773-8.

9. Russell PS, Chase CM, Winn HJ, Colvin RB: Coronary atherosclerosis in transplanted mouse hearts. II. Importance of humoral immunity. Journal of immunology (Baltimore, Md.: 1950) 1994, | 52:5135-4|.

10. Thaunat O, Louedec L, Dai J, Bellier F, Groyer E, Delignat S, Gaston A, Caligiuri G, Joly E, Plissonnier D, Michel J, Nicoletti A: Direct and indirect effects of alloantibodies link neointimal and medial remodeling in graft arteriosclerosis. Arteriosclerosis, thrombosis, and vascular biology 2006, 26:2359-65.

II. Hill GS, Nochy D, Bruneval P, Duong van Huyen JP, Glotz D, Suberbielle C, Zuber J, Anglicheau D, Empana J, Legendre C, Loupy A: Donor-specific antibodies accelerate arteriosclerosis after kidney transplantation. Journal of the American Society of Nephrology: JASN 20I I, 22:975-83.

FlOOOPrime RECOMMENDED

12. Smith RN, Kawai T, Boskovic S, Nadazdin O, Sachs DH, Cosimi AB, Colvin RB: Chronic antibody mediated rejection of renal allografts: pathological, serological and immunologic features in nonhuman primates. American journal of transplantation: official journal of the American Society of Transplantation and the American Society of Transplant Surgeons 2006, 6:1790-8.

13. Thaunat $\mathrm{O}$ : Humoral immunity in chronic allograft rejection: puzzle pieces come together. Transplant immunology 2012, 26:101-6.

14. Tan JC, Wadia PP, Coram M, Grumet FC, Kambham N, Miller K, Pereira S, Vayntrub T, Miklos DB: H-Y antibody development associates with acute rejection in female patients with male kidney transplants. Transplantation 2008, 86:75-8I.

15. Thaunat O, Graff-Dubois S, Fabien N, Duthey A, Attuil-Audenis V, Nicoletti A, Patey N, Morelon E: A stepwise breakdown of B-cell tolerance occurs within renal allografts during chronic rejection. Kidney international 2012, 81:207-19.

16. Li L, Wadia P, Chen R, Kambham N, Naesens M, Sigdel TK, Miklos DB, Sarwal MM, Butte AJ: Identifying compartment-specific nonHLA targets after renal transplantation by integrating transcriptome and "antibodyome" measures. Proceedings of the National Academy of Sciences of the United States of America 2009, 106:4|48-53.

17. Dragun D, Catar R, Philippe A: Non-HLA antibodies in solid organ transplantation: recent concepts and clinical relevance. Current opinion in organ transplantation 2013, I 8:430-5.

18. Jackson AM, Sigdel TK, Delville M, Hsieh S, Dai H, Bagnasco S, Montgomery RA, Sarwal MM: Endothelial Cell Antibodies Associated with Novel Targets and Increased Rejection. Journal of the American Society of Nephrology: JASN 2014.

19. Dragun D, Müller DN, Bräsen JH, Fritsche L, Nieminen-Kelhä M, Dechend R, Kintscher U, Rudolph B, Hoebeke J, Eckert D, Mazak I, Plehm R, Schönemann C, Unger T, Budde K, Neumayer H, Luft FC, Wallukat G: Angiotensin II type I-receptor activating antibodies in renal-allograft rejection. The New England journal of medicine 2005, 352:558-69.

\section{FIOOOPrime
RECOMMENDED}

20. Taniguchi M, Rebellato LM, Cai J, Hopfield J, Briley KP, Haisch CE, Catrou PG, Bolin P, Parker K, Kendrick WT, Kendrick SA, Harland RC, Terasaki PI: Higher risk of kidney graft failure in the presence of anti-angiotensin II type-I receptor antibodies. American journal of transplantation: official journal of the American Society of Transplantation and the American Society of Transplant Surgeons 2013, 13:2577-89.

21. Conlon TM, Saeb-Parsy K, Cole JL, Motallebzadeh R, Qureshi MS, Rehakova S, Negus MC, Callaghan C], Bolton EM, Bradley JA, Pettigrew GJ: Germinal center alloantibody responses are mediated exclusively by indirect-pathway CD4 T follicular helper cells. Journal of immunology (Baltimore, Md.: 1950) 2012, 188:2643-52.

22. Lakkis FG, Arakelov A, Konieczny BT, Inoue Y: Immunologic 'ignorance' of vascularized organ transplants in the absence of secondary lymphoid tissue. Nature medicine 2000, 6:686-8.

23. Thaunat $O$, Patey N, Caligiuri G, Gautreau C, Mamani-Matsuda M, Mekki Y, Dieu-Nosjean M, Eberl G, Ecochard R, Michel J, GraffDubois $S$, Nicoletti A: Chronic rejection triggers the development of an aggressive intragraft immune response through recapitulation of lymphoid organogenesis. Journal of immunology (Baltimore, Md.: 1950) 2010, 185:717-28.

24. Thaunat $O$, Nicoletti $A$ : Lymphoid neogenesis in chronic rejection. Current opinion in organ transplantation 2008, I3:16-9.

25. Thaunat O, Graff-Dubois S, Brouard S, Gautreau C, Varthaman A, Fabien N, Field A, Louedec L, Dai J, Joly E, Morelon E, Soulillou J, Michel J, Nicoletti A: Immune responses elicited in tertiary lymphoid tissues display distinctive features. PloS one 2010, 5: ell 398.

26. Thaunat $\mathrm{O}$ : Pathophysiologic significance of B-cell clusters in chronically rejected grafts. Transplantation 20II, 92:I2I-6.

27. Roumenina LT, Zuber J, Frémeaux-Bacchi V: Physiological and therapeutic complement regulators in kidney transplantation. Current opinion in organ transplantation 2013, I8:421-9. 
28. Hirohashi T, Uehara S, Chase CM, DellaPelle P, Madsen JC, Russell PS, Colvin RB: Complement independent antibody-mediated endarteritis and transplant arteriopathy in mice. American journal of transplantation: official journal of the American Society of Transplantation and the American Society of Transplant Surgeons 2010, 10:510-7.

\section{FIOOOPRime}

29. Loupy A, Suberbielle-Boissel C, Hill GS, Lefaucheur C, Anglicheau D, Zuber J, Martinez F, Thervet E, Méjean A, Charron D, Duong van Huyen JP, Bruneval P, Legendre C, Nochy D: Outcome of subclinical antibody-mediated rejection in kidney transplant recipients with preformed donor-specific antibodies. American journal of transplantation: official journal of the American Society of Transplantation and the American Society of Transplant Surgeons 2009, 9:2561-70.

30. Hirohashi T, Chase CM, Della Pelle P, Sebastian D, Alessandrini A, Madsen JC, Russell PS, Colvin RB: A novel pathway of chronic allograft rejection mediated by NK cells and alloantibody. American journal of transplantation: official journal of the American Society of Transplantation and the American Society of Transplant Surgeons 2012, |2:3|3-2|.

\section{FIOOOPrime}

RECOMMENDED

31. Hidalgo LG, Sis B, Sellares J, Campbell PM, Mengel M, Einecke G, Chang J, Halloran PF: NK cell transcripts and NK cells in kidney biopsies from patients with donor-specific antibodies: evidence for NK cell involvement in antibody-mediated rejection. American journal of transplantation: official journal of the American Society of Transplantation and the American Society of Transplant Surgeons 2010, 10:1812-22.

\section{FlOOOPrime}

\section{RECOMMENDED}

32. Bachelet T, Couzi L, Pitard V, Sicard X, Rigothier C, Lepreux S, Moreau J, Taupin J, Merville P, Déchanet-Merville J: Cytomegalovirus-responsive $\gamma \delta$ T cells: novel effector cells in antibodymediated kidney allograft microcirculation lesions. Journal of the American Society of Nephrology: JASN 2014, 25:247I-82.

\section{FlOOOPrime}

\section{RECOMMENDED}

33. Zhang X, Reed EF: Effect of antibodies on endothelium. American journal of transplantation: official journal of the American Society of Transplantation and the American Society of Transplant Surgeons 2009, 9:2459-65.

34. Mauiyyedi S, Pelle PD, Saidman S, Collins AB, Pascual M, TolkoffRubin NE, Williams WW, Cosimi AA, Schneeberger EE, Colvin RB: Chronic humoral rejection: identification of antibodymediated chronic renal allograft rejection by $\mathbf{C} 4 \mathrm{~d}$ deposits in peritubular capillaries. Journal of the American Society of Nephrology: JASN 200I, I 2:574-82.

35. Regele H, Böhmig GA, Habicht A, Gollowitzer D, Schillinger M, Rockenschaub S, Watschinger B, Kerjaschki D, Exner M: Capillary deposition of complement split product $\mathrm{C} 4 \mathrm{~d}$ in renal allografts is associated with basement membrane injury in peritubular and glomerular capillaries: a contribution of humoral immunity to chronic allograft rejection. Journal of the American Society of Nephrology: JASN 2002, 13:2371-80.

36. Loupy A, Jordan SC: Transplantation: Donor-specific HLA antibodies and renal allograft failure. Nature reviews. Nephrology 20।3, 9:130-I.

37. Heilman RL, Nijim A, Desmarteau YM, Khamash H, Pando MJ, Smith ML, Chakkera HA, Huskey J, Valdez R, Reddy KS: De Novo Donor-Specific Human Leukocyte Antigen Antibodies Early After Kidney Transplantation. Transplantation 2014.

38. Lefaucheur C, Loupy A, Hill GS, Andrade J, Nochy D, Antoine C, Gautreau C, Charron D, Glotz D, Suberbielle-Boissel C: Preexisting donor-specific HLA antibodies predict outcome in kidney transplantation. Journal of the American Society of Nephrology: JASN 2010, 21:1398-406.
39. Heinemann FM, Roth I, Rebmann V, Arnold M, Witzke O, Wilde B, Spriewald BM, Grosse-Wilde H: Immunoglobulin isotype-specific characterization of anti-human leukocyte antigen antibodies eluted from explanted renal allografts. Human immunology 2007, 68:500-6.

40. Hönger G, Hopfer H, Arnold M, Spriewald BM, Schaub S, Amico P: Pretransplant IgG subclasses of donor-specific human leukocyte antigen antibodies and development of antibodymediated rejection. Transplantation 20II, 92:4I-7.

\section{FlOOOPrime
RECOMMENDED}

4I. Wahrmann M, Exner M, Schillinger M, Haidbauer B, Regele $H$, Körmöczi GF, Hörl WH, Böhmig GA: Pivotal role of complement-fixing HLA alloantibodies in presensitized kidney allograft recipients. American journal of transplantation: official journal of the American Society of Transplantation and the American Society of Transplant Surgeons 2006, 6:1033-41.

\section{FIOOOPrime}

\section{RECOMMENDED}

42. Cicciarelli JC, Kasahara N, Lemp NA, Adamson R, Dembitsky W, Browne B, Steinberg S: Immunoglobulin G subclass analysis of HLA donor specific antibodies in heart and renal transplant recipients. Clinical transplants 2013:413-22.

\section{FlOOOPrime
RECOMMENDED}

43. Arnold JN, Wormald MR, Sim RB, Rudd PM, Dwek RA: The impact of glycosylation on the biological function and structure of human immunoglobulins. Annual review of immunology 2007, 25:2I-50.

44. Raju TS: Terminal sugars of Fc glycans influence antibody effector functions of IgGs. Current opinion in immunology 2008, 20:47I-8.

\section{FlOOOPrime RECOMMENDED}

45. Thaunat O, Legendre C, Morelon E, Kreis H, Mamzer-Bruneel M: To biopsy or not to biopsy? Should we screen the histology of stable renal grafts? Transplantation 2007, 84:67I-6.

46. Solez K, Colvin RB, Racusen LC, Sis B, Halloran PF, Birk PE, Campbell PM, Cascalho M, Collins AB, Demetris AJ, Drachenberg CB, Gibson IW, Grimm PC, Haas M, Lerut E, Liapis H, Mannon RB, Marcus PB, Mengel M, Mihatsch MJ, Nankivell BJ, Nickeleit V, Papadimitriou JC, Platt JL, Randhawa P, Roberts I, Salinas-Madriga L, Salomon DR, Seron D, Sheaff $M$ et al.: Banff '05 Meeting Report: differential diagnosis of chronic allograft injury and elimination of chronic allograft nephropathy ('CAN'). American journal of transplantation: official journal of the American Society of Transplantation and the American Society of Transplant Surgeons 2007, 7:5 I8-26.

47. Feucht HE, Schneeberger H, Hillebrand G, Burkhardt K, Weiss M, Riethmüller G, Land W, Albert E: Capillary deposition of C4d complement fragment and early renal graft loss. Kidney international 1993, 43:1333-8.

48. Rahimi S, Qian Z, Layton J, Fox-Talbot K, Baldwin WM, Wasowska BA: Non-complement- and complement-activating antibodies synergize to cause rejection of cardiac allografts. American journal of transplantation: official journal of the American Society of Transplantation and the American Society of Transplant Surgeons 2004, 4:326-34.

49. Loupy A, Hill GS, Suberbielle C, Charron D, Anglicheau D, Zuber J, Timsit MO, Duong JP, Bruneval P, Vernerey D, Empana JP, Jouven X, Nochy D, Legendre CH: Significance of C4d Banff scores in early protocol biopsies of kidney transplant recipients with preformed donor-specific antibodies (DSA). American journal of transplantation: official journal of the American Society of Transplantation and the American Society of Transplant Surgeons 201 I, I I:56-65.

\section{FlOOOPrime \\ RECOMMENDED}

50. Sis B, Jhangri GS, Bunnag S, Allanach K, Kaplan B, Halloran PF: Endothelial gene expression in kidney transplants with alloantibody indicates antibody-mediated damage despite 
lack of C4d staining. American journal of transplantation: official journal of the American Society of Transplantation and the American Society of Transplant Surgeons 2009, 9:2312-23.

\section{FlOOOPrime}

\section{RECOMMENDED}

5I. Haas M, Sis B, Racusen LC, Solez K, Glotz D, Colvin RB, Castro MCR, David, DSR, David-Neto E, Bagnasco SM, Cendales LC, Cornell LD, Demetris AJ, Drachenberg CB, Farver CF, Farris AB, Gibson IW, Kraus E, Liapis H, Loupy A, Nickeleit V, Randhawa P, Rodriguez ER, Rush D, Smith RN, Tan CD, Wallace WD, Mengel M: Banff 2013 meeting report: inclusion of $\mathrm{c} 4 \mathrm{~d}$-negative antibody-mediated rejection and antibody-associated arterial lesions. American journal of transplantation: official journal of the American Society of Transplantation and the American Society of Transplant Surgeons 2014, 14:272-83.

52. Gebel HM, Bray RA: Laboratory assessment of HLA antibodies circa 2006: making sense of sensitivity. Transplantation Reviews 2006, 20:189-94.

53. Garovoy MR, Rheinschmidt MA: Flow cytometry analysis: a high technology crossmatch technique facilitating transplantation. Transplant Proc 1983, I 5:1939-44.

54. Kao KJ, Scornik JC, Small SJ: Enzyme-linked immunoassay for anti-HLA antibodies-an alternative to panel studies by lymphocytotoxicity. Transplantation 1993, 55:192-6.

55. Pei R, Lee J, Shih N, Chen M, Terasaki PI: Single human leukocyte antigen flow cytometry beads for accurate identification of human leukocyte antigen antibody specificities. Transplantation 2003, 75:43-9.

56. Gebel HM, Bray RA: HLA antibody detection with solid phase assays: great expectations or expectations too great? American journal of transplantation: official journal of the American Society of Transplantation and the American Society of Transplant Surgeons 2014, I4:1964-75.

57. Guidicelli G, Anies G, Bachelet T, Dubois V, Moreau J, Merville P, Couzi L, Taupin J: The complement interference phenomenon as a cause for sharp fluctuations of serum anti-HLA antibody strength in kidney transplant patients. Transplant immunology 20I3, 29:|17-2I.

58. Süsal C, Ovens J, Mahmoud K, Döhler B, Scherer S, Ruhenstroth A, Tran TH, Heinold A, Opelz G: No association of kidney graft loss with human leukocyte antigen antibodies detected exclusively by sensitive Luminex single-antigen testing: a Collaborative Transplant Study report. Transplantation 201I, 91:883-7.

\section{FIOOOPrime}

59. Bachelet T, Couzi L, Lepreux S, Legeret M, Pariscoat G, Guidicelli G, Merville $\mathrm{P}$, Taupin J: Kidney intragraft donor-specific antibodies as determinant of antibody-mediated lesions and poor graft outcome. American journal of transplantation: official journal of the American Society of Transplantation and the American Society of Transplant Surgeons 2013, 13:2855-64.

\section{FIOOOPrime}

60. Loupy A, Lefaucheur C, Vernerey D, Chang J, Hidalgo LG, Beuscart T, Verine J, Aubert O, Dubleumortier S, Duong van Huyen, Jean-Paul, Jouven X, Glotz D, Legendre C, Halloran PF: Molecular microscope strategy to improve risk stratification in early antibody-mediated kidney allograft rejection. Journal of the American Society of Nephrology: JASN 2014, 25:2267-77.

\section{FlOOOPrime}

RECOMMENDED

61. Lefaucheur C, Nochy D, Hill GS, Suberbielle-Boissel C, Antoine C, Charron D, Glotz D: Determinants of poor graft outcome in patients with antibody-mediated acute rejection. American journal of transplantation: official journal of the American Society of Transplantation and the American Society of Transplant Surgeons 2007, 7:832-41.
62. Sicard A, Ducreux S, Rabeyrin M, Couzi L, McGregor B, Badet L, Scoazec JY, Bachelet T, Lepreux S, Visentin J, Merville P, FremeauxBacchi V, Morelon E, Taupin J, Dubois V, Thaunat O: Detection of C3d-binding donor-specific anti-HLA antibodies at diagnosis of humoral rejection predicts renal graft loss. Journal of the American Society of Nephrology: JASN 2015, 26:457-67.

63. Loupy A, Lefaucheur C, Vernerey D, Prugger C, Duong van Huyen, Jean-Paul, Mooney N, Suberbielle C, Frémeaux-Bacchi V, Méjean A, Desgrandchamps F, Anglicheau D, Nochy D, Charron D, Empana J, Delahousse M, Legendre C, Glotz D, Hill GS, Zeevi A, Jouven $X$ : Complement-binding anti-HLA antibodies and kidney-allograft survival. The New England journal of medicine 2013, 369:1215-26.

\section{FIOOOPrime}

64. Bartel G, Wahrmann M, Schwaiger E, Kikić Ž, Winzer C, Hörl WH, Mühlbacher F, Hoke M, Zlabinger GJ, Regele H, Böhmig GA: Solid phase detection of C4d-fixing HLA antibodies to predict rejection in high immunological risk kidney transplant recipients. Transplant international: official journal of the European Society for Organ Transplantation 2013, 26:121-30.

65. Diebolder CA, Beurskens FJ, de Jong, Rob N, Koning RI, Strumane K Lindorfer MA, Voorhorst M, Ugurlar D, Rosati S, Heck Albert JR, van de Winkel, Jan GJ, Wilson IA, Koster AJ, Taylor RP, Saphire EO, Burton DR, Schuurman J, Gros P, Parren, Paul WHI: Complement is activated by IgG hexamers assembled at the cell surface. Science (New York, NY) 2014, 343:1260-3.

66. Zand MS, Vo T, Huggins J, Felgar R, Liesveld J, Pellegrin T, Bozorgzadeh A, Sanz I, Briggs BJ: Polyclonal rabbit antithymocyte globulin triggers B-cell and plasma cell apoptosis by multiple pathways. Transplantation 2005, 79:1507-15.

67. Kazatchkine MD, Kaveri SV: Immunomodulation of autoimmune and inflammatory diseases with intravenous immune globulin. The New England journal of medicine 200I, 345:747-55.

68. Lefaucheur C, Nochy D, Andrade J, Verine J, Gautreau C, Charron D, Hill GS, Glotz D, Suberbielle-Boissel C: Comparison of combination Plasmapheresis/IVIg/anti-CD20 versus high-dose IVIg in the treatment of antibody-mediated rejection. American journal of transplantation: official journal of the American Society of Transplantation and the American Society of Transplant Surgeons 2009, 9:1099-107.

\section{FlOOOPrime
RECOMMENDED}

69. Böhmig GA, Wahrmann M, Regele H, Exner M, Robl B, Derfler K, Soliman T, Bauer P, Müllner M, Druml W: Immunoadsorption in severe C4d-positive acute kidney allograft rejection: a randomized controlled trial. American journal of transplantation: official journal of the American Society of Transplantation and the American Society of Transplant Surgeons 2007, 7:117-21.

70. Gupta G, Abu Jawdeh, Bassam G, Racusen LC, Bhasin B, Arend LJ, Trollinger B, Kraus E, Rabb H, Zachary AA, Montgomery RA, Alachkar N: Late antibody-mediated rejection in renal allografts: outcome after conventional and novel therapies. Transplantation 2014, 97: 1240-6.

7I. Faguer S, Kamar N, Guilbeaud-Frugier C, Fort M, Modesto A, Mari A, Ribes D, Cointault O, Lavayssière L, Guitard J, Durand D, Rostaing L: Rituximab therapy for acute humoral rejection after kidney transplantation. Transplantation 2007, 83:1277-80.

72. An GH, Yun J, Hong YA, Khvan M, Chung BH, Choi BS, Park CW, Choi YJ, Kim Y, Yang CW: The effect of combination therapy with rituximab and intravenous immunoglobulin on the progression of chronic antibody mediated rejection in renal transplant recipients. Journal of immunology research 2014, 2014:828732.

73. Sautenet B, Blancho G, Buchler M, Morelon E, Toupance O, Barrou B, Ducloux D, Hurault de Ligny B, Moulin B, Le Gouge A, Lebranchu Y: One Year Results of the Effects of Rituximab on Acute Humoral Rejection in Renal Transplantation: RITUX ERAH, a Multicenter Randomized Placebo Controlled Trial [abstract]. Presented at 2013 American Transplant Congress: 18-22 May 2013, Seattle, WA. 
74. Kamar N, Milioto O, Puissant-Lubrano B, Esposito L, Pierre MC, Mohamed AO, Lavayssière L, Cointault O, Ribes D, Cardeau I, Nogier MB, Durand D, Abbal M, Blancher A, Rostaing L: Incidence and predictive factors for infectious disease after rituximab therapy in kidney-transplant patients. American journal of transplantation: official journal of the American Society of Transplantation and the American Society of Transplant Surgeons 2010, 10:89-98.

\section{FlOOOPrime
RECOMMENDED}

75. Hychko G, Mirhosseini A, Parhizgar A, Ghahramani N: A Systematic Review and Meta-Analysis of Rituximab in Antibodymediated Renal Allograft Rejection. International journal of organ transplantation medicine 201 I, 2:5I-6.

76. Tillou X, Poirier N, Le Bas-Bernardet S, Hervouet J, Minault D, Renaudin K, Vistoli F, Karam G, Daha M, Soulillou JP, Blancho G: Recombinant human $\mathrm{Cl}$-inhibitor prevents acute antibodymediated rejection in alloimmunized baboons. Kidney international 2010, 78:152-9.

77. Zuraw BL, Busse PJ, White M, Jacobs J, Lumry W, Baker J, Craig T, Grant JA, Hurewitz D, Bielory L, Cartwright WE, Koleilat M, Ryan W, Schaefer O, Manning M, Patel P, Bernstein JA, Friedman RA, Wilkinson R, Tanner D, Kohler G, Gunther G, Levy R, McClellan J, Redhead J, Guss D, Heyman E, Blumenstein BA, Kalfus I, Frank MM: Nanofiltered $\mathrm{Cl}$ inhibitor concentrate for treatment of hereditary angioedema. The New England journal of medicine 2010, 363:513-22.

78. Hillmen P, Young NS, Schubert J, Brodsky RA, Socié G, Muus P, Röth A, Szer J, Elebute MO, Nakamura R, Browne P, Risitano AM, Hill A, Schrezenmeier H, Fu C, Maciejewski J, Rollins SA, Mojcik CF, Rother RP, Luzzatto L: The complement inhibitor eculizumab in paroxysmal nocturnal hemoglobinuria. The New England journal of medicine 2006, 355: I 233-43.

79. Zuber J, Le Quintrec M, Krid S, Bertoye C, Gueutin V, Lahoche A, Heyne N, Ardissino G, Chatelet V, Noël L, Hourmant M, Niaudet P, Frémeaux-Bacchi V, Rondeau E, Legendre C, Loirat C: Eculizumab for atypical hemolytic uremic syndrome recurrence in renal transplantation. American journal of transplantation: official journal of the American Society of Transplantation and the American Society of Transplant Surgeons 2012, 12:3337-54.
80. Barnett A, Nicholas R, Asgari E, Chowdhury P, Sacks SH, Dorling A Mamode $\mathrm{N}$ : The use of eculizumab in renal transplantation. Clinical transplantation 2013, 27:E216-29.

8I. Stegall MD, Diwan T, Raghavaiah S, Cornell LD, Burns J, Dean PG, Cosio FG, Gandhi MJ, Kremers W, Gloor JM: Terminal complement inhibition decreases antibody-mediated rejection in sensitized renal transplant recipients. American journal of transplantation: official journal of the American Society of Transplantation and the American Society of Transplant Surgeons 201 I, I I:2405-I 3.

82. Perry DK, Burns JM, Pollinger HS, Amiot BP, Gloor JM, Gores GJ, Stegall MD: Proteasome inhibition causes apoptosis of normal human plasma cells preventing alloantibody production. American journal of transplantation: official journal of the American Society of Transplantation and the American Society of Transplant Surgeons 2009, 9:201-9.

83. Everly MJ, Everly JJ, Susskind B, Brailey P, Arend LJ, Alloway RR, RoyChaudhury P, Govil A, Mogilishetty G, Rike AH, Cardi M, Wadih G, Tevar A, Woodle ES: Bortezomib provides effective therapy for antibody- and cell-mediated acute rejection. Transplantation 2008, 86:|754-6I.

84. Liefeldt L, Brakemeier S, Glander $\mathrm{P}$, Waiser J, Lachmann $\mathrm{N}$, Schönemann C, Zukunft B, Illigens P, Schmidt D, Wu K, Rudolph B, Neumayer H, Budde K: Donor-specific HLA antibodies in a cohort comparing everolimus with cyclosporine after kidney transplantation. American journal of transplantation: official journal of the American Society of Transplantation and the American Society of Transplant Surgeons 2012, I 2: I 192-8.

85. Serre J, Michonneau D, Bachy E, Noël L, Dubois V, Suberbielle C, Kreis H, Legendre C, Mamzer-Bruneel M, Morelon E, Thaunat O: Maintaining calcineurin inhibition after the diagnosis of posttransplant lymphoproliferative disorder improves renal graft survival. Kidney international 2014, 85: 182-90.

86. Chesneau M, Michel L, Degauque N, Brouard S: Regulatory B cells and tolerance in transplantation: from animal models to human. Frontiers in immunology 2013, 4:497.

87. Zeng $\mathrm{Q}, \mathrm{Ng} \mathrm{Y}$, Singh $\mathrm{T}$, jiang K, Sheriff KA, Ippolito R, Zahalka S, Li Q, Randhawa P, Hoffman RA, Ramaswami B, Lund FE, Chalasani G: B cells mediate chronic allograft rejection independently of antibody production. The Journal of clinical investigation 2014, I 24: 1052-6. 